\title{
Curtovirus Infection of Chile Pepper in New Mexico
}

\author{
R. Creamer, H. Hubble, and A. Lewis, Department of Entomology, Plant Pathology, and Weed Science, New Mex- \\ ico State University, Las Cruces 88003
}

\begin{abstract}
Creamer, R., Hubble, H., and Lewis, A. 2005. Curtovirus infection of chile pepper in New Mexico. Plant Dis. 89:480-486.

Chile pepper-producing areas of southern New Mexico (NM) were surveyed during 2001 and 2002 to identify which curtoviruses were infecting chile peppers and to determine the distribution of the viruses among fields. Plants with symptoms resembling Beet curly top virus (BCTV) were collected from 10 fields and tested for the presence of curtoviruses by polymerase chain reaction using primers designed to detect a portion of the coat protein $(c p)$ gene, and tested for specific curtoviruses using primers designed to detect to a portion of the replication-associated protein (rep) gene. All amplicons were sequenced and compared with curtoviruses for which complete sequences were available. Amplification was successful from $79.5 \%$ of the chile pepper samples. Analysis of the CP sequences showed that more than $92 \%$ of the NM field isolates shared high (98 to 100\%) amino acid identity with well-characterized curtoviruses. However, eight NM isolates displayed a distinct $\mathrm{CP}$ sequence that shared only 86 to $88 \%$ amino acid identity with those curtoviruses. Comparison of the rep gene sequence showed that $18.5 \%$ of the NM field isolates tested shared 98 to $100 \%$ amino acid identity with Beet mild curly top virus (BMCTV), 48\% shared 96 to $97 \%$ amino acid identity with Beet severe curly top virus (BSCTV), and 32\% shared 93 to $97 \%$ amino acid identity with BMCTV and BSCTV. Although the distribution of curtoviruses was not identical among all fields sampled, little or no spatial patterns were found among the field isolates. This study revealed the complexity of curtoviruses in a single crop and limited geographical area.
\end{abstract}

Beet curly top virus (BCTV) has caused significant problems to irrigated agriculture in the western United States since 1899 (7). In New Mexico, curly top disease is sporadic, but caused substantial losses to chile pepper (Capsicum annuum L.) in 3 of the past 10 years. During the 2001 and 2003 growing seasons, many fields in southwestern New Mexico experienced losses of 30 to 50 and 20 to $30 \%$, respectively (8).

Curtoviruses infect a broad range of hosts that includes crops and weeds from many plant families (2). In New Mexico, curly top symptoms have been described in chile pepper, tomato, bean, spinach, and cucurbits. Severe stunting symptoms typically occur when chile pepper is infected with BCTV. Virus-infected plants are often yellow and, if infected early, do not produce fruit.

BCTV is transmitted in a persistent circulative manner by the beet leafhopper Circulifer tenellus (Baker) (2). In California, leafhoppers are believed to acquire virus from weeds on which they overwin-

Corresponding author: R. Creamer

E-mail: creamer@taipan.nmsu.edu

This work was supported by the New Mexico State University Agricultural Experiment Station.

Accepted for publication 15 December 2004.

DOI: 10.1094/PD-89-0480

(C) 2005 The American Phytopathological Society ter in the coastal foothills. During the spring in California, adult leafhoppers migrate into agricultural areas where they transmit the virus to susceptible crops. The migratory patterns of the beet leafhopper have not been as well studied in southern New Mexico. However, as occurs in California, the leafhoppers are thought to overwinter on weeds and build up to high numbers in the summer (8).

BCTV is a monopartite geminivirus and the type member of the genus Curtovirus in the family Geminiviridae. Viruses in this group are characterized by circular singlestranded (ss)DNA genomes of approximately $3.0 \mathrm{~kb}$ encapsidated within twin spherical particles. Many strains of BCTV initially were distinguished on the basis of differential symptoms in sugar beet (12); however, these strains were not differentiated genetically. In sugar beet (Beta vulgaris L.), BCTV primarily exists as three strains, CFH (16), Worland (19, 21), or California/Logan (15), as well as genotypic variants of these strains (20). The California/Logan strain has been identified only from breeding collections (21). Nucleotide sequence comparisons have shown that the California and Logan isolates share more than $95 \%$ similarity, while CFH shares approximately $82 \%$ similarity with California and Logan isolates (21). Nucleotide sequence identity between $\mathrm{CFH}$ and Worland is $80 \%$. Given the differences between the CFH, Worland, and California/Logan strains, Stenger (18) proposed that they be designated as sepa- rate species with the names Beet severe curly top virus (BSCTV), Beet mild curly top virus (BMCTV), and BCTV, respectively. Another Curtovirus, Horseradish curly top virus (HrCTV), is thought to be a natural recombinant with a whitefly-vectored Begomovirus (13). Recently, an additional Curtovirus, Spinach curly top virus (SCTV) was reported infecting spinach in Texas (1).

Curtoviruses contain seven open reading frames (ORFs) designated V1 to V3 (encoded by the virion or sense strand) and $\mathrm{C} 1$ to $\mathrm{C} 4$ (encoded by the complimentary or antisense strand). ORF V1 encodes the coat protein $(\mathrm{CP})$, which is required for infectivity, packaging, and leafhopper transmission. The $c p$ is also one of the most highly conserved genes among curtoviruses (19), as well as among geminiviruses in general (4). V2 has been associated with the production and accumulation of viral ssDNA (11). ORF $\mathrm{C} 1$ encodes the replication-associated protein (REP) (6), which is required for BCTV replication, and acts by binding to DNA sequences in the viral intergenic region (10). The REP protein contains regions of varying degrees of conservation among curtoviruses (9), including a hypervariable region near the amino terminus. Studies involving gene chimeras have determined that the rep genes are interchangeable only among certain curtoviruses (18).

Surveys of Curtovirus isolates infecting sugar beets in Idaho (21), Texas (17), and the western United States have been conducted (20). These studies found primarily the $\mathrm{CFH}$ or Worland strains, with some mixed infections of the two strains. A limited survey of BCTV strains in sugar beet and pepper in one area of New Mexico found that $\mathrm{CFH}$ was limited to sugar beet, whereas pepper was infected only with the Worland strain (20). A small survey of BCTV in weeds in New Mexico showed that Worland was predominant, although $\mathrm{CFH}$ also was present (8).

This work was conducted to determine which curtoviruses infect chile pepper in southern New Mexico. In addition, we studied the diversity among isolates from different fields collected during two field seasons to determine if there were spatial patterns in Curtovirus infection of chile pepper in New Mexico.

\section{MATERIALS AND METHODS}

Collection of pepper samples. Plant samples were collected from 10 chile pep- 
per fields located in Luna and Doña Ana Counties in southern New Mexico and two fields during the 2001 and 2002 growing seasons, respectively. Samples were composed of randomly collected leaves from symptomatic pepper plants collected in June and July 2001 and August 2002. Samples collected in 2002 were from chile pepper fields only in the vicinity of those sampled in 2001 because the same fields were not planted in pepper the second year of the study.

DNA extraction and polymerase chain reaction. Leaf tissue $(5 \mathrm{~g})$ was ground in liquid nitrogen with a mortar and pestle. Powdered material was either stored at $-20^{\circ} \mathrm{C}$ or immediately extracted. DNA was extracted essentially as described by Palmer et al. (14). Extracted viral nucleic acids were stored in Tris-EDTA, pH 7.0, at $-20^{\circ} \mathrm{C}$.

All samples initially were tested for curtoviruses by polymerase chain reaction (PCR) using primers (CP3) that amplify a portion of the $\mathrm{CP}$ and $\mathrm{V} 2$ encoding regions as described previously (8). A modified set of primers (BCTV CP4f, 5'-CAGTATCGACCAGTTGTTT-3' homologous to nucleotides 483 to 501 of BSCTV-CFH, and BCTV CP6r, 5'-CTCTTCGAATACGATAAGTAG-3' complementary to nucleotides 1,102 to 1,122 of BSCTV$\mathrm{CFH})$ were used to amplify a 576-bp fragment for sequencing. All samples also were tested for Curtovirus identity using primers that amplify a 488-bp portion of the rep region (BCTV rep1f, 5'-ACCACCTTTAATGACACGT-3' homologous to nucleotides 2,043 to 2,061 of BSCTVCFH, and BCTV rep2r, 5'-GCATTAAATGCAGGTAATGCA-3' complementary to nucleotides 2,511 to 2,531 of BSCTV-CFH). These primers also were used for DNA sequencing.

PCR reactions were carried out in a 50$\mu \mathrm{l}$ reaction mixture containing $1 \times \mathrm{PCR}$ buffer (10 mM Tris-HCl, pH 8.3, $50 \mathrm{mM}$ $\mathrm{KCl}, 0.001 \%$ gelatin), $200 \mu \mathrm{M}$ each dNTP, $1.5 \mathrm{mM} \mathrm{MgCl} 2,500 \mu \mathrm{M}$ each primer, $4 \mathrm{U}$ Taq DNA polymerase, and $1 \mu \mathrm{l}$ of purified
DNA. PCR amplification consisted of 33 cycles of $94^{\circ} \mathrm{C}$ for $30 \mathrm{~s}, 51^{\circ} \mathrm{C}$ for $60 \mathrm{~s}$, and $72^{\circ} \mathrm{C}$ for $90 \mathrm{~s}$, followed by a final extension of $72^{\circ} \mathrm{C}$ for $5 \mathrm{~min}$. Amplification products were separated by electrophoresis on a $2 \%$ agarose gel and the bands visualized with ethidium bromide.

Sequencing, cloning, and phylogenetic analyses of amplicons. PCR products were precipitated directly to remove excess primers and nucleotides using isopropanol (100 $\mu \mathrm{l}$ of $90 \%$ isopropanol/0.75 M ammonium acetate). Sequencing was carried out on the PCR products using the Big Dye version 3.1 terminator system and an ABI 3100 sequencer (Applied Biosystems, Foster City, CA).

To ensure that the sequences obtained were not artifacts from sequencing a mixture of PCR products, selected amplicons were inserted in a pGEM-T Easy vector (Promega Corp., Madison, WI) by TA cloning and the resultant plasmids introduced into JM109 cells. The plasmid inserts were amplified and sequenced as above.

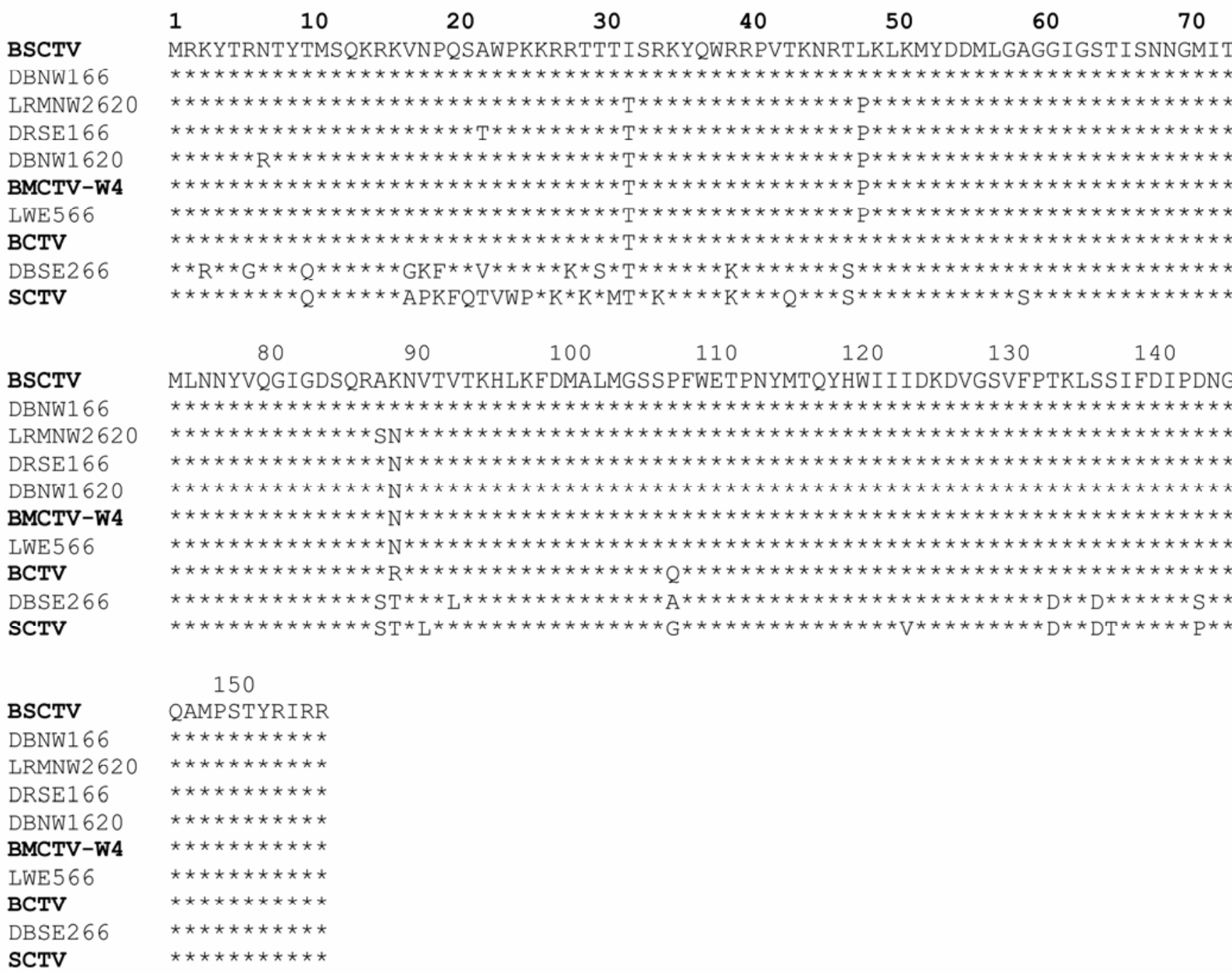

Fig. 1. Comparison of the first 157 amino acids of the coat protein (CP) of selected New Mexico chile pepper Curtovirus field isolates with previously characterized curtoviruses available in GenBank. Asterisks denote amino acid residues common with Beet severe curly top virus (BSCTV), (U02311). BCTV = Beet curly top virus(AY379637); BMCTV = Beet mild curly top virus, (AY13467); SCTV = Spinach curly top virus, (AY548948). Each field isolate shown is an example of a group of chile pepper Curtovirus isolates as listed in Table 1. 
Nucleic acid and derived amino acid sequences were aligned using CLUSTALW with those of the following curtoviruses obtained from GenBank: BCTV (AY379637), BSCTV (U02311), BMCTVW4 (AY13467), BMCTV-Worland (U56975), and SCTV (AY548948). Phylogenetic analysis of the sequences was done using PAUP version $4.0 \mathrm{~b}$ (24) using parsimony. Support for the trees was determined by analysis of 1,000 bootstrap replications. Potato yellow mosaic virus (GenBank accession AY126610) was used as an outgroup to root the tree.

\section{RESULTS}

Detection of curly top virus by PCR. Curtoviruses were amplified from 201 of $253(79.5 \%)$ chile pepper field samples collected over the two seasons using a combination of primer sets. The CP3 primer set failed to amplify from 11 sam- ples that were successfully amplified using the rep1f-rep2r primer set, which prompted the switch to the CP4f-CP6r primer set. These primers amplified an additional 28 samples. In 2001, curtoviruses were identified in $87.1 \%$ of the chile pepper samples; whereas, in 2002, curtoviruses were amplified from only $33.3 \%$ of the samples tested.

PCR amplicons of $v 2-c p$ from 107 New Mexico chile pepper samples were sequenced and aligned with the homologous sequences from well-characterized curtoviruses in GenBank. An alignment of the corresponding amino acids from several of these samples is shown in Figures 1 and 2. For 99 of the field isolates (represented by isolates DBNN166, LRMNM2620, DRSE166, DBNM1620, and LWE566; Fig. 1 and Table 1), the first 157 amino acids (aa) from CP shared 96 to $100 \%$ identity with BMCTV-W4 and BSCTV
(GenBank \#U02311). Most of the 99 isolates shared at least $98 \%$ amino acid identity with BMCTV-W4 or BSCTV. The New Mexico isolates shared 97 to $100 \%$ amino acid identity with each other, varying by only 1 to 2 aa. Some sequence variants were more prevalent, with nine other isolates containing the amino acid sequence found in LWE566 (Table 1).

The remaining eight isolates (DBSW666, DBSE566, DC7620, DRNE1A66, AG3E276, LJNW176, LS266, and DBSE266, with the latter as an example in Table 1 and Fig. 1) were highly similar to each other at the nucleotide level (99 to $100 \%$ identity). However, these isolates shared only 86 to $88 \%$ amino acid identity with BMCTV-W4 and BSCTV.

There also was variability found within the last 87 aa (no. 40 to 126) of the V2 protein (Fig. 2). The same 99 isolates mentioned above shared 93 to $100 \%$ amino

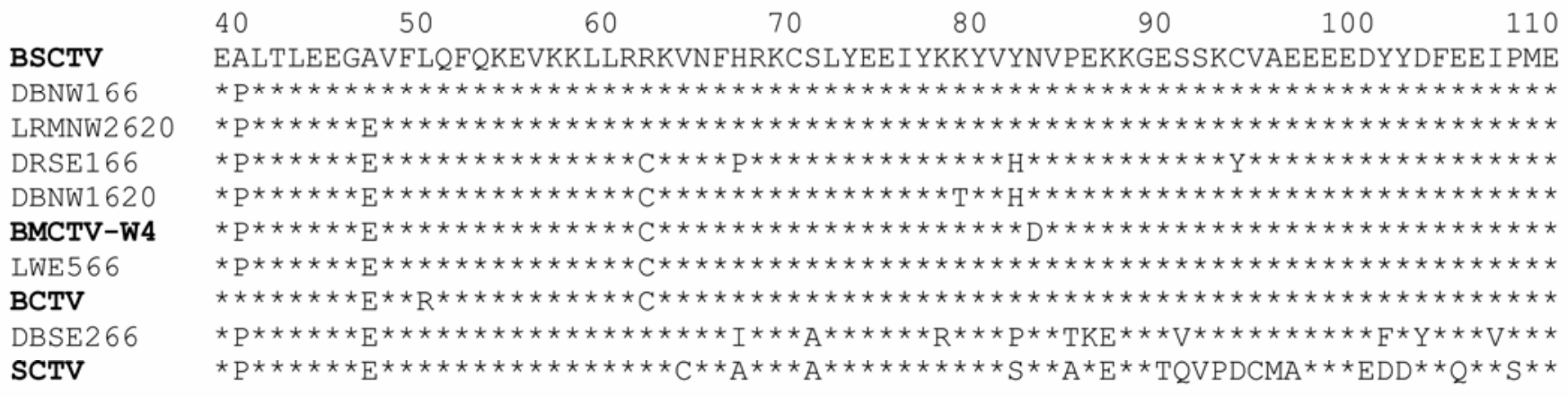

120

\begin{tabular}{|c|c|}
\hline BSCTV & ETCDKKQDSEVKDV \\
\hline DBNW1 66 & 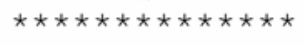 \\
\hline RMNW 2620 & 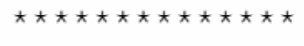 \\
\hline 166 & 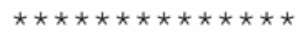 \\
\hline NW1 620 & 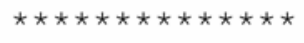 \\
\hline CTV-W4 & 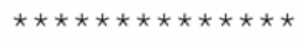 \\
\hline 566 & 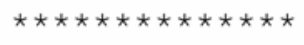 \\
\hline I"T) & 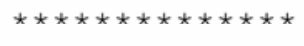 \\
\hline $\mathrm{E} 2$ & 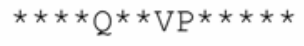 \\
\hline & $\star \star \star A \star A E$ \\
\hline
\end{tabular}

Fig. 2. Comparison of the amino acids 40 to 126 of the V2 protein of selected New Mexico Curtovirus chile pepper field isolates with previously characterized curtoviruses available in GenBank. Asterisks denote amino acid residues common with Beet severe curly top virus $(\mathrm{BSCTVU02311)}$. BCTV $=$ Beet curly top virus, (AY379637); BMCTV = Beet mild curly top virus, (AY13467); SCTV = Spinach curly top virus, (AY548948). Each field isolate shown is an example of a group of chile pepper Curtovirus isolates as listed in Table 1.

Table 1. Comparison of percent amino acid identity among coat protein $(\mathrm{CP})$ and $\mathrm{V} 2$ regions of New Mexico Curtovirus isolates from chile pepper with four characterized curtoviruses available in GenBank ${ }^{\mathrm{a}}$

\begin{tabular}{|c|c|c|c|c|c|c|c|c|c|}
\hline \multirow[b]{2}{*}{ Isolate } & \multirow[b]{2}{*}{ No. of isolates ${ }^{b}$} & \multicolumn{2}{|c|}{ BMCTV-W4 } & \multicolumn{2}{|c|}{ BSCTV } & \multicolumn{2}{|c|}{ BCTV } & \multicolumn{2}{|c|}{ SCTV } \\
\hline & & $\mathbf{C P}$ & $\mathbf{V 2}$ & $\mathbf{C P}$ & $\mathbf{V 2}$ & $\mathbf{C P}$ & $\mathbf{V 2}$ & $\mathbf{C P}$ & V2 \\
\hline DBNW166 & 2 & 98 & 96 & 100 & 98 & 98 & 95 & 84 & 73 \\
\hline LRMNW2620 & 5 & 99 & 97 & 97 & 95 & 97 & 96 & 84 & 74 \\
\hline DRSE166 & 9 & 99 & 97 & 97 & 93 & 97 & 94 & 84 & 73 \\
\hline DBNW1620 & 8 & 99 & 96 & 97 & 94 & 96 & 95 & 84 & 71 \\
\hline LWE566 & 10 & 100 & 99 & 98 & 97 & 98 & 98 & 84 & 73 \\
\hline DBSE266 & 4 & 87 & 82 & 88 & 82 & 89 & 80 & 83 & 70 \\
\hline
\end{tabular}

a BMCTV = Beet mild curly top virus, (AY113467); BSCTV = Beet severe curly top virus, (U02311); BCTV = Beet curly top virus, (AY379637); SCTV = Spinach curly top virus, (AY548948). Isolate designations include the county, field, location in the field, and date (i.e., DRSE166 = Doña Ana County, Rincon Field, southeast quadrant, sample 1, collected 6/6/01).

b Number of chile pepper Curtovirus isolates that share $100 \%$ amino acid identity among CP and V2 regions with the isolate in the first column. 
acid identity with BMCTV-W4 or BSCTV, with most isolates sharing 95 to $98 \%$ amino acid identity with one of the two curtoviruses (Table 1). The same eight remaining isolates described above (see DBSE266 as an example) also were highly similar (99 to $100 \%$ nucleotide identity) to each other in the $v 2$ region, but shared only 80 to $82 \%$ amino acid identity with BMCTV-W4 and BSCTV and 72 to $74 \%$ amino acid identity with SCTV.

Variation in the Rep region. Primers used to amplify rep (rep1f/rep2r) yielded a 488-bp fragment that was sequenced for 151 field samples. After alignment, the isolates were separated into three groups based on nucleic acid and amino acid homology (Fig. 3). One group of 72 isolates (see isolates DBNW1620, DBSE366, DBNW366, LKSE1620, and DCE5620 as examples) shared 96 to $97 \%$ amino acid identity with BSCTV (Table 2, Fig. 4) and shared 98 to $100 \%$ amino acid identity with each other. Thirty-nine of these isolates (see DBNW16120 as an example) shared the same amino acid sequence. A second group of 28 isolates (see isolates LRMNW21620, LWE566, DB98602, and DB2466 as examples) shared 98 to $100 \%$ amino acid sequence identity with BMCTV-W4 (Table 2, Fig. 4).

The third group consisted of 48 isolates (see isolates DBNE266, LWN1620, and DRSE166 as examples) that had sequences that shared a high level of identity with both BSCTV and BMCTV (Table 2, Fig. 4), which we have labeled New Mexico (NM) unknown. These isolates shared 99 to $100 \%$ amino acid identity with one another, and 94 and $97 \%$ amino acid identity with BSCTV and BMCTV, respectively. Twenty-nine of these isolates (see DBNE266 as an example) shared the same amino acid sequence (Table 2, Fig. 4).

A fourth grouping, with three isolates (LKW276, LWE766, and DB2666), also had sequences that shared a high level of identity with both BSCTV and BMCTV (Table 2, Fig. 4). These isolates shared nucleotide identities of $92 \%$ with BSCTV and $91 \%$ with BMCTV, and shared identities of 95,96 , and $98 \%$ with BSCTV, BMCTV, and NM unknown, respectively.

Spatial and temporal distribution of curly top isolates. Curtoviruses, as distinguished by REP sequence, were not equally distributed among all fields. However, little spatial or temporal clustering of isolates was observed. Doña Ana County field $B$ yielded 17 different REP sequences. In all, 8 isolates of BMCTV, 16 isolates of the NM unknown, and 15 isolates most similar to BSCTV were collected from the field (Table 3). Chile peppers infected with BMCTV, NM unknown, and BSCTV were collected at all sampling dates during both years in field B. In contrast, Luna County field RM yielded six different REP sequences, including 2 iso-

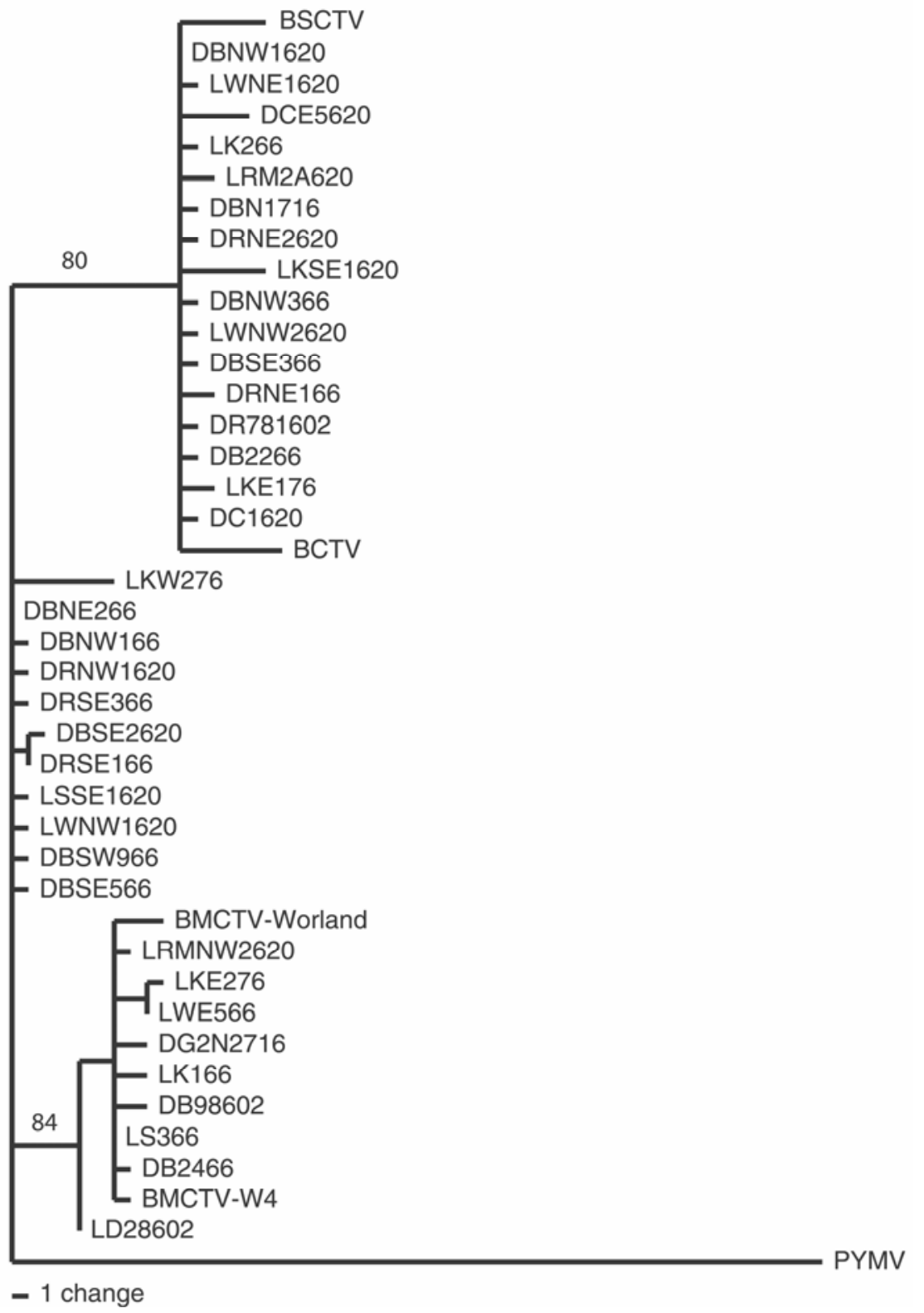

Fig. 3. Phylogenetic comparison of replication-associated protein amino acids 133 to 279 of selected New Mexico chile pepper Curtovirus isolates with Beet severe curly top virus (BSCTV), Beet mild curly top virus (BMCTV), and Beet curly top virus (BCTV). Numbers represent result of 1,000 bootstrap replications using parsimony. BSCTV = GenBank no. U02311; BCTV = AY379637; BMCTV = AY13467.

Table 2. Comparison of percent amino acid sequence identity among replication-associated proteins of New Mexico chile pepper Curtovirus isolates with previously characterized curtoviruses available in GenBank ${ }^{\mathrm{a}}$

\begin{tabular}{lccccc}
\hline Isolate & No. of $^{\text {isolates }}{ }^{\mathbf{b}}$ & BMCTV-W4 & BSCTV & BCTV & SCTV \\
\hline LRMNW2620 & 6 & 100 & 90 & 90 & 92 \\
LWE566 & 6 & 99 & 91 & 90 & 92 \\
DB98602 & 1 & 98 & 89 & 88 & 91 \\
DB2466 & 5 & 99 & 91 & 89 & 90 \\
DBNE266 & 29 & 97 & 94 & 90 & 95 \\
LWN1620 & 1 & 97 & 93 & 91 & 92 \\
DRSE166 & 11 & 97 & 93 & 91 & 94 \\
LKW276 & 3 & 96 & 94 & 94 & 92 \\
DBNW1620 & 39 & 91 & 97 & 95 & 90 \\
DBSE366 & 7 & 91 & 97 & 96 & 91 \\
DBNW366 & 2 & 92 & 97 & 95 & 90 \\
LKSE1620 & 1 & 90 & 95 & 92 & 90 \\
DCE5620 & 2 & 91 & 97 & 95 & 90 \\
\hline
\end{tabular}

${ }^{\mathrm{a}}$ BMCTV = Beet mild curly top virus, $(\mathrm{AY} 113467) ; \mathrm{BSCTV}=$ Beet severe curly top virus, $(\mathrm{U} 02311)$ BCTV = Beet curly top virus, (AY379637); SCTV = Spinach curly top virus, (AY548948). Isolate designations include the county, field, location in the field, and date (i.e., DRSE166 = Doña Ana County, Rincon Field, southeast quadrant, sample 1, collected 6/6/01)

${ }^{\mathrm{b}}$ Number of chile pepper Curtovirus isolates that share $100 \%$ amino acid identity with the isolate in the first column. 
lates of BMCTV, 1 isolate of NM unknown, and 14 isolates of BSCTV (Table 3). This field yielded plants infected with BMCTV, NM unknown, and BSCTV at the 6 June 2001 sampling date, and only BSCTV and BMCTV isolates at subsequent sampling dates, 16 June through 15 July 2001.

Little spatial clustering occurred among isolates with similar sequences. For example, of the 11 samples with the NM unknown REP sequence found in DRSE166, 9 were collected from four fields within Doña Ana County and 1 each from two different fields in Luna County (Table 3). Similarly, the six samples with the BMCTV REP sequence identified in
LWE566 were collected in both 2001 and 2001 from two different fields in Doña Ana County and two in Luna County. There was no discernable temporal clustering of isolates. All isolates that were collected at least five times were found at each sampling date in 2001.

Although the eight isolates with the distinct $c p$ sequence found in DBSE266 were collected in 2001, they showed little spatial clustering. Six isolates were collected from four Doña Ana County fields: three of the six isolates from field $\mathrm{B}$, and the other three isolates from three different fields in the county. Two of the eight isolates were collected from two different fields in Luna County.

\section{DISCUSSION}

At least three different Curtovirus strains were detected from chile peppers collected from southern New Mexico. The majority of the isolates were collected during 2001, when the incidence of curly top was 10 to $30 \%$ in the region (8). In 2002 , curly top incidence was much lower ( 0.5 to $1 \%$ ), and $66.7 \%$ of the samples were not infected with any known curtoviruses, suggesting that some of the typical Curtovirus symptoms of chlorosis and stunting observed on plants during that year were due to causes other than curtoviruses.

When the New Mexico isolates were differentiated into two groups based on $c p$

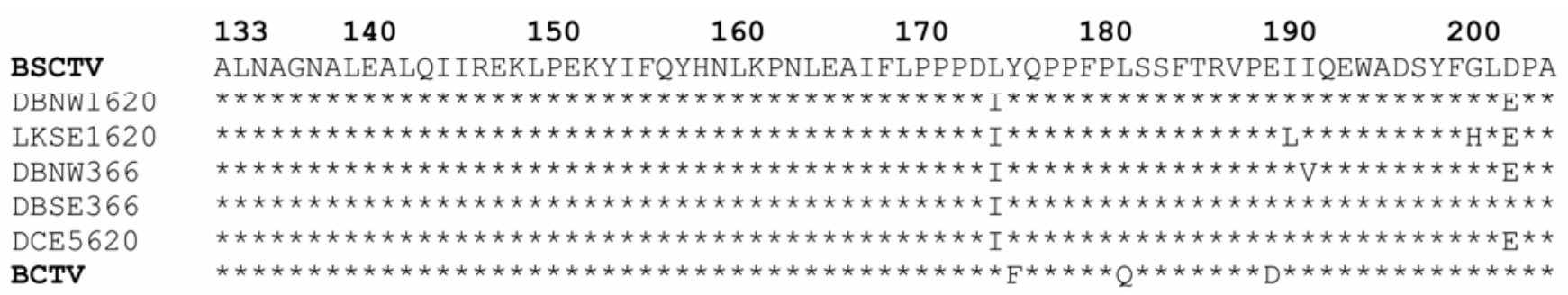

\section{DBNE2 66 \\ LWN1 620 \\ DRSE1 66 \\ LKW276

BMCTV-Wor
LRMNW2620
LWE5 66
DB98602
DB2466
BMCTV-4
SCTV

BSCTV
DBNW1620
LKSE1620
DBNW366
DBSE366
DCE5620
BCTV

DBNE2 66
LWNW1 620
DRSE1 66
LKW276

BMCTV-Wor
LRMNW 2620
LWE 566
DB98602
DB2 466
BMCTV-W4
SCTV

Fig. 4. Comparison of replication-associated protein amino acids 133 to 279 of selected New Mexico chile pepper Curtovirus field isolates with previously characterized curtoviruses available in GenBank. Asterisks denote amino acid residues common with Beet severe curly top virus $(\mathrm{BSCTV}$ U02311). BCTV = Beet curly top virus, (AY379637); BMCTV = Beet mild curly top virus, (AY13467); SCTV = Spinach curly top virus, (AY548948). The chile pepper Curtovirus field isolates shown correspond to the New Mexico isolates listed in Table 2. 
sequence, not surprisingly, the majority of Curtovirus isolates from chile pepper formed a tight phylogenetic cluster. This gene showed little sequence variation (17), as expected, given its role in encapsidation and insect transmission $(5,6)$. Maize streak virus, another leafhopper-transmitted Geminivirus, also has a highly conserved $\mathrm{CP}$, with isolates from different geographic locations showing only $2 \%$ sequence divergence at the amino acid level (4). In contrast, the eight isolates with the variant $\mathrm{CP}$ sequence differed from other geminiviruses. The isolates have unique amino acid residues not common to other curtoviruses or begomoviruses. Cloning and sequencing of the virus isolates is necessary to determine whether the changes are due to recombination as with $\mathrm{HrCTV}$ (13), Beet pseudo curly top virus (3), and possibly SCTV (1).

Consistent with previous work (8), BSCTV-CFH and BMCTV-Worland were found in infected chile pepper. The presence of the alternative rep sequence (NM unknown) was more surprising and likely is due to a new curly top strain or significant divergence from a characterized strain. Although the high homology with both BSCTV and BMCTV might be suggestive of a mixture of virus isolates within the samples, sequences from cloned amplicons showed that this had not occurred. The alternative rep sequence could be the result of recombination; however, the large number $(>30 \%)$ of samples with this sequence suggests that any recombination was not a recent event. Surveys of other states will need to be conducted to determine whether virus containing the NM unknown rep sequence is found in other areas of the western United States.

Stenger and McMahon (20) suggested that two virus genotypes found in sugar beet that were intermediate between Worland and $\mathrm{CFH}$ may be highly diverged examples of Worland. The NM unknown isolate or strain, although not identical to these two genotypes, may be an example of greater divergence from Worland. However, sequencing of the entire viral genome is necessary to determine whether this has occurred. With REP sequences intermediate between BSCTV and BMCTV, NM unknown and the two divergent genotypes found in sugar beet might be considered as part of a continuum of Curtovirus strains between BSCTV and BMCTV. Additional surveys of curtoviruses from other crops and geographic areas will be necessary to test this possibility.

The lack of clearly defined spatial clustering of the chile pepper Curtovirus isolates may be due to several factors. The lack of spatial patterns likely is due to a very large, diverse source of virus isolates, especially given the very large weed host population known for curly top viruses (2). New Curtovirus infection may have occurred repeatedly in a field due to flights of vector leafhoppers into the fields during the cropping season. In the same 10 fields surveyed for curtoviruses for this work, beet leafhoppers were found in very large numbers in 2001 (8). During that year, leafhopper populations in these fields showed at least four peaks of flight activity. Each flight of leafhoppers likely originated from a different location or from different weed hosts. Ongoing studies comparing the strains of curtoviruses in chile pepper with those in adjacent weed hosts will help resolve whether this occurred. In addition, the lack of clustering suggests little secondary spread within a field. This may be due to the nonpreference of the vector for chile pepper as a colonization or reproductive host. As an example, the beet leafhopper has been shown to transmit curtoviruses to nonpreferred hosts, such as tomato, with high efficiency (23). Most likely, a combination of all these scenarios occurs.

\section{ACKNOWLEDGMENTS}

We thank the New Mexico Chile Task Force for identifying field sites, J. Carpenter for helping collect field isolates, and the New Mexico State University Agricultural Experiment Station for supporting this work.

\section{LITERATURE CITED}

1. Balij, S., Black, M. C., French, R., Stenger, D. C., and Sunter, G. 2004. Spinach curly top virus: A newly described Curtovirus species from southwest Texas with incongruent gene phylogenies. Phytopathology 94:772-779.

2. Bennett, C. W. 1971. The Curly Top Disease of Sugarbeet and Other Plants. Monograph 7. The American Phytopathological Society, St. Paul, MN.

3. Briddon, R. W., Bedford, I. D., Tsai, J. H., and Markham, P. G. 1996. Analysis of the nucleotide sequence of the treehopper-transmitted geminivirus, tomato pseudo-curly top virus, suggests a recombinant origin. Virology 219:387-394.

4. Briddon, R. W., Lunness, P., Chamberlin, L. C. L., and Markham, P. G. 1994. Analysis of the genetic variability of maize streak virus. Virus Genes 9:93-100.

5. Briddon, R. W., Pinner, M. S., Stanley, J., and Markham, P. G. 1990. Geminivirus coat protein gene replacement alters insect specificity. Virology 177:85-94.

6. Briddon, R. W., Watts, J., Markham, P. G., and Stanley, J, 1989. The coat protein of beet curly top virus is essential for infectivity. Virology 172:628-633.

7. Carsner, E., and Stahl, C. F. 1924. Studies on curly-top disease of the sugarbeet. J. Agric. Res. 28:297-320.

8. Creamer, R., Carpenter, J., and Rascon, J. 2003. Incidence of the beet leafhopper, Circulifer tenellus (Homoptera:Cicadellidae) in New Mexico chile. Southwest. Entomol. 28:177-182.

9. Choi, I.-R., and Stenger, D. C. 1995. Strainspecific determinants of beet curly top gemi-

Table 3. Distribution of Curtovirus isolates with a specific replication-associated protein (REP) amino acid sequence among chile pepper fields in Doña Ana Co. and Luna Co. New Mexico

\begin{tabular}{|c|c|c|c|c|c|c|c|c|c|c|}
\hline \multirow[b]{3}{*}{ Isolate $^{a}$} & \multirow[b]{3}{*}{ No. of isolates ${ }^{b}$} & \multicolumn{9}{|c|}{ No. of isolates with REP amino acid sequence collected from each field } \\
\hline & & \multicolumn{4}{|c|}{ Doña Ana County fields } & \multicolumn{5}{|c|}{ Luna County fields } \\
\hline & & B & $\mathbf{R}$ & $\mathbf{C}$ & $\mathbf{G}$ & $\mathbf{R M}$ & $\mathbf{W}$ & $\mathbf{K}$ & $\mathbf{J}$ & $\mathbf{S}$ \\
\hline LRMNW2620 & 6 & 2 & 1 & 1 & 0 & 2 & 0 & 0 & 0 & 0 \\
\hline LWE566 & 6 & 1 & 0 & 0 & 2 & 0 & 1 & 0 & 2 & 0 \\
\hline DB2466 & 5 & 1 & 1 & 1 & 0 & 0 & 0 & 1 & 1 & 0 \\
\hline DBSW1620 & 4 & 3 & 0 & 1 & 0 & 0 & 0 & 0 & 0 & 0 \\
\hline$\ldots$ & 9 & 1 & 0 & 0 & 2 & 0 & 1 & 2 & 0 & 1 \\
\hline DBNE266 & 29 & 10 & 6 & 2 & 3 & 0 & 1 & 2 & 3 & 2 \\
\hline DRSE166 & 11 & 2 & 2 & 3 & 2 & 1 & 1 & 0 & 0 & 0 \\
\hline$\ldots$ & 8 & 4 & 2 & 0 & 0 & 0 & 1 & 0 & 0 & 1 \\
\hline LKW276 & 3 & 1 & 0 & 0 & 0 & 0 & 1 & 1 & 0 & 0 \\
\hline DBNW1620 & 39 & 7 & 4 & 3 & 6 & 9 & 3 & 0 & 3 & 4 \\
\hline DBSE366 & 7 & 4 & 1 & 2 & 0 & 0 & 0 & 0 & 0 & 0 \\
\hline LRMS 1620 & 3 & 0 & 0 & 0 & 0 & 3 & 0 & 0 & 0 & 0 \\
\hline DC1620 & 2 & 0 & 0 & 2 & 0 & 0 & 0 & 0 & 0 & 0 \\
\hline DCE5620 & 2 & 0 & 0 & 2 & 0 & 0 & 0 & 0 & 0 & 0 \\
\hline DBNW366 & 2 & 2 & 0 & 0 & 0 & 0 & 0 & 0 & 0 & 0 \\
\hline DRNE166 & 2 & 0 & 2 & 0 & 0 & 0 & 0 & 0 & 0 & 0 \\
\hline$\ldots$ & 13 & 2 & 3 & 0 & 0 & 2 & 3 & 4 & 0 & 0 \\
\hline Total & 151 & 40 & 22 & 17 & 15 & 17 & 12 & 10 & 9 & 8 \\
\hline
\end{tabular}

a ... Indicates isolates that do not share $100 \%$ sequence homology with any other isolate.

b Number of chile pepper Curtovirus isolates that share $100 \%$ amino acid identity with the isolate in the first column. 
nivirus DNA replication. Virology 206:904-912.

10. Choi, I.-R., and Stenger, D. C. 1996. The strain-specific cis-acting element of beet curly top virus geminivirus DNA replication maps to the directly repeated motif of the ori. Virology 226:122-126.

11. Hormuzdi, S. G., and Bisaro, D. M. 1993. Genetic analysis of beet curly top virus: Evidence for three virion sense genes involved in movement and regulation of single- and double-stranded DNA levels. Virology 193:900909.

12. Isnard, M., Granier, M., Frutos, R., Reynaud, and Peterschmitt, M. 1998. Quasispecies nature of three maize streak virus isolates obtained through different modes of selection from a population used to assess response to infection of maize cultivars. J. Gen. Virol. 79:3091-3099.

13. Klein, M. 1992. Role of Circulifer/Neoaliturus in the transmission of plant pathogens. Pages 152-193 in: Advances in Disease Vector Research, Vol. 9. Springer-Verlag, NY.

14. Klute, K. A. Nadler, S. A., and Stenger, D. C.
1996. Horseradish curly top virus is a distinct subgroup II geminivirus species with rep and C4 genes derived from a subgroup III ancestor. J. Gen. Virol. 77:1369-1378.

15. Palmer, K. E., Schnippenkoetter, W. H., and Rybicki, E. P. 1998. Geminivirus isolation and DNA extraction. Pages 41-52 in: Methods in Molecular Biology, Vol. 81. G. D. Foster and S. C. Taylor, eds. Humana Press Inc., Totowa, NJ.

16. Stanley, J., Markham, P. G., Callis, R. J., and Pinner, M. S. 1986. The nucleotide sequence of an infectious clone of the geminivirus beet curly top virus. EMBO J. 5:1761-1767.

17. Stenger, D. C. 1994. Complete nucleotide sequence of the hypervirulent $\mathrm{CFH}$ strain of beet curly top virus. Mol. Plant-Microbe Interact. 7:154-157.

18. Stenger, D. C. 1995. Genotypic variability and the occurrence of less than genome-length viral DNA forms in a field population of beet curly top geminivirus. Phytopathology 85:1316-1322.

19. Stenger, D. C. 1998. Replication specificity elements of the Worland strain of beet curly top virus are compatible with those of the $\mathrm{CFH}$ strain but not those of the Cal/Logan strain. Phytopathology 88:1174-1178

20. Stenger, D. C., Carbonaro, D., and Duffus, J. E. 1990. Genomic characterization of phenotypic variants of beet curly top virus. J. Gen. Virol. 71:2211-2215.

21. Stenger, D. C., Davis, K. R., and Bisaro, D. M. 1994. Recombinant beet curly top virus genomes exhibit both parental and novel pathogenic phenotypes. Virology 200:677-685.

22. Stenger, D. C., and McMahon, C. L. 1997 Genotypic diversity of beet curly top virus populations in the western United States. Phytopathology 87:737-744

23. Stenger, D. C., and Ostrow, K. M. 1996. Genetic complexity of a beet curly top virus population used to assess sugar beet cultivar response to infection. Phytopathology 86:929. 933.

24. Swofford, D. 1997. PAUP: Phylogenetic Analysis Using Parsimony (and other methods). Sinauer Associates, Sunderland, MA. 